\title{
Papillomavirus Protein E4
}

National Cancer Institute

\section{Source}

National Cancer Institute. Papillomavirus Protein E4. NCI Thesaurus. Code C20052.

A nonstructural protein of unknown function. It localizes to keratin filaments and so may

have a role in virus release by disturbing the integrity of the infected cell. (from Virology

1996;218:114-26) 